\title{
DAYA TERIMA DAN KANDUNGAN PROTEIN BISKUIT SUBSTITUSI TEPUNG UBI JALAR UNGU DAN ISOLAT PROTEIN KEDELAI UNTUK PEMBERIAN MAKANAN TAMBAHAN IBU HAMIL KEK
}

\author{
The Acceptance and Protein Content of Biscuits Substitutes with Purple Sweet Potato Flour and \\ Soy Protein Isolates for Supplementary Food of Chronic Energy Deficiency Pregnant Woman \\ Iga Ayuni Fatmala ${ }^{1}$, Annis Catur Adi ${ }^{2}$ \\ ${ }^{1}$ Program studi S1 Ilmu Gizi, Fakultas Kesehatan Masyarakat, Universitas Airlangga Surabaya \\ ${ }^{2}$ Departemen Gizi Kesehatan, Fakultas Kesehatan Masyarakat, Universitas Airlangga Surabaya \\ Email: fatmalaiga@gmail.com
}

\begin{abstract}
ABSTRAK
Penggunaan tepung ubi jalar ungu dan isolat protein kedelai untuk diolah menjadi biskuit berpotensi menjadi Pemberian Makanan Tambahan (PMT)yang tepat untuk ibu hamil Kurang Energi Kronis (KEK) daripada biskuit yang beredar di pasaran. Penelitian ini bertujuan untuk mengetahui daya terima dan kandungan protein pada biskuit yang disubstitusi tepung ubi jalar ungu dan isolat protein kedelai. Penelitian ini adalah penelitian eksperimental murni dengan rancangan acak lengkap (RAL) yang memiliki 6 kali pengulangan. Terdapat 3 formula biskuit yang diteliti yaitu 1 formula biskuit kontrol (F0) dan 2 formula biskuit modifikasi (F1, F2). Jumlah substitusi tepung ubi jalar pada F1 (170 g) dan F2 (90 g), sedangkan jumlah substitusi isolat protein kedelai pada F1 (30 g) dan F2 (10 g). Data dianalisis dengan analisis deskriptif dan dianalisis secara inferensia menggunakan uji beda Kruskal Wallis dan uji lanjut Mann Whitney. Hasil penelitian ini menunjukkan bahwa penilaian biskuit secara umum dapat diterima baik oleh ibu hamil dengan nilai rata-rata daya terima tertinggi adalah biskuit F2. Penilaian daya terima pada karakteristik warna dan aroma tertinggi adalah F0, karakteristik tekstur tertinggi adalah F1 serta pada karakteristik rasa adalah F2. Penilaian warna, aroma, rasa antar formula tidak berbeda secara signifikan $(\alpha>0,05)$, sedangkan pada karakteristik tekstur berbeda secara signifikan $(\alpha<0,05)$. Formula terbaik (F2) memiliki daya terima yang paling tinggi dan kandungan protein sebesar 11,9 g per 100 g yang dapat mencukupi 10\% kebutuhan protein ibu hamil sehingga layak digunakan sebagai pemberian makanan tambahan (PMT) ibu hamil.
\end{abstract}

Kata kunci: biskuit, ibu hamil, isolat protein kedelai, tepung ubi jalar ungu

\begin{abstract}
The use of purple sweet potato flour and soy protein isolates to be processed into protein biscuit has a good potential to be an appropriate supplementary food for chronic energy deficiency (CED) pregnant woman compared to biscuits commercialized on market. This research aimed to investigate the acceptance and protein content of biscuits that had been substituted with purple sweet potato flour and soy protein isolates. This research was true experimental design with completely randomized design (RAL) with 6 repetitions. There was 3 formulas which were 1 control formula (F0) and 2 modified formulas (F1, F2). The total of purple sweet potato flour substitution on F1 was $170 \mathrm{~g}$ and F2 was 90 $g$, meanwhile the total of soy protein isolate substitution on F1 was $30 \mathrm{~g}$ and F2 was $10 \mathrm{~g}$. The data was analyzed by applying descriptive analyses which was tested by Kruskal Wallis and Mann Whitney to find the effect among formulas. The result of this research showed that generally the assessment of biscuit was well accepted by pregnant woman and the highest average of acceptance was F2 formula. The assessment of the highest acceptance for color and aroma characteristic was F2. The assessment of color, aroma, and taste among formulas had no significant impact ( $\alpha<0.05)$, meanwhile on texture characteristic there was significant effect $(\alpha>0.05)$. The best formula (F2) has a good acceptance and posses protein content of $11.9 \mathrm{~g}$ per $100 \mathrm{~g}$ that can fulfill the need of $10 \%$ protein for pregnant woman so it can be used as supplementary food for pregnant woman.
\end{abstract}

Keywords: biscuit, pregnant woman, soy protein isolate, purple sweet potato flour 


\section{PENDAHULUAN}

Kondisi hamil menyebabkan terjadinya peningkatan kebutuhan gizi pada ibu hamil, namun masih banyak ibu hamil yang kurang mencukupi kebutuhan gizinya terutama kebutuhan protein (Muliawati, 2013). Pada penelitian yang dilakukan oleh Ausa, dkk. (2013) menunjukkan bahwa $48 \%$ responden (ibu hamil) kurang mencukupi kebutuhan protein, penelitian tersebut di dukung oleh penelitian Syari, dkk. (2015) terdapat 27,5\% ibu hamil yang tidak mencukupi kebutuhan protein harian. Hal tersebut dapat menjadi penyebab kekurangan energi kronis (KEK) pada ibu hamil yang berdampak pada menurunnya kesehatan ibu dan janin (Supariasa, dkk., 2002).

Perlunya pemberian makanan tambahan (PMT) sebagai salah satu upaya untuk meningkatkan asupan protein pada ibu hamil. Syarat utama PMT ibu hamil adalah dapat diterima baik oleh ibu hamil (Kemenkes RI, 2010).

Biskuit merupakan salah satu produk makanan yang dterima baik oleh masyarakat, termasuk ibu hamil dikarenakan rasanya yang enak, memiliki masa simpan yang lama, mudah dikonsumsi dimana dan kapan saja (Asmoro, dkk., 2012). Biskuit dapat menjadi salah satu media dalam perbaikan zat gizi apabila ditambahkan dengan bahan tertentu (Mervina, dkk., 2012). Biskuit memerlukan pengembangan pangan lokal untuk menggantikan tepung terigu yang menjadi bahan utama dalam pengolahannya. Hal tersebut dikarenakan tepung terigu berasal dari gandum yang tidak dapat ditanam di Indonesia sehingga harus ekspor dari negara lain (Mayasari, 2015).

Pangan lokal yang dapat dijadikan sebagai alternatif pengganti tepung terigu adalah tepung yang berasal dari umbi-umbian yaitu ubi jalar ungu (Ipomoea batatas L.Poir). Tepung ubi jalar ungu memiliki sifat kimia yang serupa dengan tepung terigu seperti kadar abu, kadar serat, kalori sehingga dapat menggantikan tepung terigu (Hardoko dan Siregar, 2010).

Penggunaan tepung ubi jalar ungu dalam pengolahan biskuit juga meningkatkan pemanfaatan ubi jalar ungu yang masih terbatas hingga sat ini (Marta dan Tensiska, 2013), selain itu kandungan antosianin dalam pigmen tepung ubi jalar ungu dapat meningkatkan tampilan warna produk biskuit (Rosidah, 2014). Antosianin pada ubi jalar ungu juga berfungsi sebagai antioksidan untuk mencegah dari senyawa oksidasi yang dapat mengakibatkan kerusakan sel serta menurunkan kesehatan ibu hamil (Kemenkes RI, 2014).

Kacang kedelai merupakan jenis kacangkacangan yang tinggi akan protein, bahkan nilai Protein Efisiensi Rasio (PER) pada kacang kedelai setara dengan protein hewani (Ekafitri dan Isworo, 2014). Kandungan protein pada kedelai sebesar 40,40 g per 100 g (Direktorat Gizi Departemen Kesehatan RI, 1981). Kandungan protein pada kedelai lebih meningkat apabila dalam bentuk isolat. Isolat protein kedelai merupakan bentuk kedelai dengan kandungan protein paling tinggi yaitu mencapai $95 \%$. Hal tersebut membuat isolat protein kedelai tepat digunakan untuk formulasi makanan (Koswara, 2013).Tujuan penelitian ini adalah mengetahui daya terima dan kandungan protein pada biskuit yang disubstitusi dengan tepung ubi jalar ungu dan isolat protein kedelai sebagai alternatif PMT untuk ibu hamil.

\section{METODE PENELITIAN}

Penelitian ini adalah eksperimental murni dengan rancang bangun penelitian rancangan acak lengkap (RAL) dengan 6 (enam) kali pengulangan. Penelitian dilakukan pada bulan Maret-Juli tahun 2017. Pembuatan biskuit dilakukan di Laboratorium Gizi Universitas Airlangga Surabaya, Uji organoleptik di Puskesmas Keputih Surabaya, dan Uji kandungan protein dilakukan di Laboratorium Gizi Universitas Airlangga Surabaya.

Sampel dari penelitian ini adalah biskuit substitusi tepung ubi jalar ungu dan isolat protein kedelai dengan jumlah substitusi yang telah ditetapkan.

Sampel biskuit untuk dinilai panelis disajikan dalam ukuran 10 gram pada masing-masing formula. Sampel diambil secara acak dari hasil pengulangan pada masing-masing formula.

Sampel yang disajikan kepada panelis kemudian dinilai karakteristiknya yaitu meliputi warna, aroma, tekstur dan rasa yang merupakan rangsangan produk yang dapat dikenali oleh alat indera (organoleptik) (Agusman, 2013). Penilaian 
karakteristik biskuit menggunakan angket uji kesukaan sehingga dapat dilihat biskuit yang mendapat nilai tingkat kesukaan tertinggi dari panelis merupakan biskuit yang memiliki daya terima yang tertinggi. Panelis pada penelitian ini adalah panelis tidak terlatih yaitu 30 orang ibu hamil di wilayah kerja Puskesmas Keputih Surabaya.

Tabel 1. Formula Biskuit Tepung Ubi Jalar Ungu dan Isolat Protein Kedelai

\begin{tabular}{lccc}
\hline \multirow{2}{*}{\multicolumn{1}{c}{ Komposisi (g) }} & \multicolumn{3}{c}{ Formula } \\
\cline { 2 - 4 } & F0 & F1 & F2 \\
\hline Tepung terigu & 400 & 200 & 300 \\
Tepung ubi jalar ungu & 0 & 170 & 90 \\
Isolat protein kedelai & 0 & 30 & 10 \\
Margarin & 200 & 200 & 200 \\
Gula halus & 120 & 120 & 120 \\
Kuning telur & 4 & 4 & 4 \\
Susu bubuk & 16 & 16 & 16 \\
Baking powder & 1 & 1 & 1 \\
Vanili & 2 & 2 & 2 \\
\hline
\end{tabular}

Bahan yang digunakan pada pembuatan biskuit di penelitian ini adalah tepung terigu, tepung ubi jalar ungu, isolat protein kedelai, margarin, gula halus, susu bubuk full cream, kuning telur, baking powder, vanili. Formulasi biskuit tepung ubi jalar ungu dan isolat protein kedelai pada penelitian ini disajikan pada Tabel 1. Pembuatan biskuit substitusi tepung ubi jalar ungu dan isolat protein kedelai menggunakan metode krim yaitu memisahkan antara bahan kering dan bahan pembentuk butter (Claudia dkk, 2015). Bahan pembentuk butter yaitu gula halus, margarin, vanili, baking powder dimasukkan terlebih dahulu ke dalam bread marker kemudian dicampur dengan bahan kering yaitu tepung terigu, tepung ubi jalar ungu, dan isolat protein kedelai secara perlahan hingga terbentuk adonan. Adonan biskuit yang sudah tercampur hingga kalis kemudian di gulung menggunakan roll kayu untuk mendapatkan ketebalan yang optimal yaitu $0,4 \mathrm{~cm}$ dengan diameter sebesar $3 \mathrm{~cm}$, lalu dicetak menggunakan cetakan kue (panjang 4 $\mathrm{cm}$ dan lebar $3 \mathrm{~cm}$ ). Adonan yang sudah dicetak kemudian ditata diatas loyang lalu dimasukkan oven dengan suhu $180^{\circ} \mathrm{C}$ selama 25 menit.
Penelitian pada penelitian ini adalah penilaian daya terima yang diperoleh dari uji tingkat kesukaan menggunakan angket uji kesukaan dan penghitungan kadar protein berdasarkan Nutrisurvey 2007 yang mengacu pada DKBM (1981). Formula biskuit substitusi tepung ubi jalar ungu dan isolat protein kedelai yang memiliki daya terima tertinggi kemudian diuji laboratorium untuk diuji kembali kadar proteinnya dengan metode kjeldhal. Teknik analisis data yang digunakan adalah analisis deskriptif dan analisis statistik Kruskal Wallis dan Mann Whitney.

Penelitian ini menyertakan manusia sebagai subjek penelitian yaitu sebagai panelis untuk menilai daya terima biskuit. Penelitian ini telah lolos uji etik dari komisi etik penelitian kesehatan No. 253-KEPK Fakultas Kesehatan Masyarakat Universitas Airlangga Surabaya.

\section{HASIL DAN PEMBAHASAN}

Hasil uji daya terima pada 30 orang ibu hamil yang merupakan panelis tidak terlatih terhadap tingkat kesukaan pada karakteristik warna biskuit dapat dilihat di Tabel 2. Tabel 2 menunjukkan karakteristik warna biskuit yang paling disukai oleh panelis adalah biskuit F0 (biskuit kontrol) dengan nilai mean rank (rata-rata) 49,23. Selisih nilai mean rank tingkat kesukaan pada karakteristik warna hanya sedikit sehingga biskuit F1 dan F2 juga disukai oleh panelis tidak terlatih. Warna biskuit F0 adalah kuning kecokelatan, sedangkan warna biskuit modifikasi adalah ungu kecokelatan. Semakin banyak tepung ubi jalar ungu dan isolat protein kedelai yang disubstitusikan dalam pembuatan biskuit, semakin biskuit berwarna kecokelatan. Biskuit F1 yang menjadi substitusi paling banyak berwarna cokelat gelap. Proses sebuah produk makanan menjadi berwarna kecokelatan setelah dipanaskan (dioven) disebut browning non-enzimatis atau yang sering disebut reaksi maillard (Koeswardhani, 2016). Reaksi maillard disebabkan oleh gugus karbonil yang terdapat pada karbohidrat dari tepung ubi jalar ungu berikatan dengan asam amino yang terdapat pada protein dari isolat protein kedelai yang terjadi pada suhu tinggi (Winarno, 2004). 
Tabel 2. Distribusi Tingkat Kesukaan Panelis Terhadap Karakteristik Biskuit

\begin{tabular}{|c|c|c|c|c|c|c|c|c|c|c|c|}
\hline \multirow{3}{*}{ Karakteristik } & \multicolumn{8}{|c|}{ Tingkat Kesukaan } & \multirow{2}{*}{\multicolumn{2}{|c|}{ Total }} & \multirow{3}{*}{ Mean Rank } \\
\hline & \multicolumn{2}{|c|}{1} & \multicolumn{2}{|c|}{2} & \multicolumn{2}{|c|}{3} & \multicolumn{2}{|c|}{4} & & & \\
\hline & n & $\%$ & $\mathrm{n}$ & $\%$ & $\mathrm{n}$ & $\%$ & $\mathrm{n}$ & $\%$ & n & $\%$ & \\
\hline \multicolumn{12}{|l|}{ Warna } \\
\hline F0 & 0 & 0,00 & 4 & 13,33 & 16 & 53,34 & 10 & 33,33 & 30 & 100,00 & 49,23 \\
\hline F1 & 2 & 6,67 & 4 & 13,33 & 16 & 53,33 & 8 & 26,67 & 30 & 100,00 & 42,07 \\
\hline $\mathrm{F} 2$ & 3 & 10,00 & 3 & 10,00 & 15 & 50,00 & 9 & 30,00 & 30 & 100,00 & 45,20 \\
\hline \multicolumn{12}{|l|}{ Aroma } \\
\hline F0 & 0 & 0,00 & 6 & 20,00 & 18 & 60,00 & 6 & 20,00 & 30 & 100,00 & 47,90 \\
\hline $\mathrm{F} 1$ & 2 & 6,67 & 5 & 16,67 & 18 & 60,00 & 5 & 16,66 & 30 & 100,00 & 44,88 \\
\hline $\mathrm{F} 2$ & 2 & 6,67 & 7 & 23,33 & 15 & 50,00 & 6 & 20,00 & 30 & 100,00 & 43,72 \\
\hline \multicolumn{12}{|l|}{ Tekstur } \\
\hline F0 & 4 & 13,33 & 18 & 60,00 & 8 & 26,67 & 0 & 0,00 & 30 & 100,00 & 30,80 \\
\hline F1 & 4 & 13,33 & 2 & 6,67 & 17 & 56,67 & 7 & 23,33 & 30 & 100,00 & 53,52 \\
\hline F2 & 4 & 13,33 & 2 & 6,67 & 12 & 40,00 & 9 & 3,00 & 30 & 100,00 & 52,18 \\
\hline \multicolumn{12}{|l|}{ Rasa } \\
\hline F0 & 1 & 1,33 & 4 & 13,33 & 15 & 50,00 & 10 & 33,33 & 30 & 100,00 & 44,77 \\
\hline F1 & 2 & 6,67 & 6 & 20,00 & 14 & 46,67 & 8 & 26,67 & 30 & 100,00 & 39,53 \\
\hline $\mathrm{F} 2$ & 1 & 1,33 & 5 & 16,67 & 7 & 23,33 & 7 & 56,67 & 30 & 100,00 & 52,20 \\
\hline
\end{tabular}

Keterangan : 1 = sangat tidak suka, 2 = tidak suka, 3 = suka, $4=$ sangat suka

Aroma adalah rangsangan dari makanan yang diterima oleh lidah. Aroma menjadi salah satu karakteristik yang penting dalam menentukan daya terima suatu produk makanan (Fiani dan Japarianto, 2012). Tabel 2 menunjukkan karakteristik aroma biskuit yang paling disukai oleh panelis adalah biskuit F0 dengan nilai mean rank sebesar 47,90.

Aroma biskuit $\mathrm{F} 0$ adalah khas margarin, sedangkan aroma biskuit F1 dan F2 adalah khas margarin dan khas kedelai (terasa langu). Semakin banyak substitusi tepung ubi jalar ungu dan isolat protein kedelai pada biskuit, semakin tajam aroma langu pada biskuit. Hal tersebut dikarenakan adanya enzim lipoksigenase pada kedelai yang menjadi bahan utama isolat protein kedelai yang menghidrolisis lemak kedelai sehingga timbul aroma langu (Santoso, 2005).

Tekstur produk makanan dapat mempengaruhi rasa pada produk makanan tersebut yang berakibat pada penerimaan produk tersebut pada panelis (Winarno, 2004). Tabel 2 menunjukkan karakteristik tekstur biskuit yang paling disukai adalah F1 dengan nilai mean rank sebesar 53,52. Tekstur biskuit adalah renyah namun terdapat perbedaan tingkat kerenyahan antar biskuit dikarenakan perbedaan jumlah substitusi tepung ubi jalar ungu dan isolat protein kedelai pada pengolahan biskuit. Tekstur biskuit modifikasi (F1 dan F2) lebih renyah dan lebih disukai oleh panelis dibandingkan dengan biskuit kontrol (F0).

Biskuit F1 lebih renyah dibandingkan dengan formula biskuit lainnya dikarenakan proporsi tepung ubi jalar ungu dan isolat protein kedelai yang disubstitusikan pada pengolahan biskuit paling banyak dari pada biskuit lainnya. Kadar pati yang tinggi pada tepung ubi jalar ungu dapat mengikat air pada saat proses gelatinisasi sehingga menyebabkan biskuit menjadi renyah setelah dioven (Williams dan Margareth, 2001). Lesitin pada isolat protein kedelai juga memiliki karakteristik sebagai pengemulsi dan dapat mengikat air sehingga dapat memperbaiki tekstur pada biskuit (Mervina, 2009).

Rasa merupakan karakteristik paling penting dalam penentuan daya terima biskuit. Rasa dapat timbul disebabkan oleh bahan makanan itu sendiri atau disebabkan karena penambahan zat lain (Endrasari dan Nugraheni, 2012). Tabel 2 
menunjukkan karakteristik rasa biskuit yang paling disukai oleh panelis adalah biskuit $\mathrm{F} 2$ dengan nilai mean rank sebesar 52,20.

Rasa biskuit kontrol dan modifikasi adalah manis, namun pada biskuit modifikasi timbul after taste pahit. Semakin banyaknya substitusi tepung ubi jalar ungu dan isolat protein kedelai pada biskuit maka semakin terasa after taste pahit pada biskuit. Rasa pahit tersebut disebabkan oleh soyasaponin dan sapogenol yang merupakan senyawa glikosida yang terdapat pada kedelai sebagai bahan utama isolat protein kedelai (Purwanto dan Hersoelistyorini, 2011).

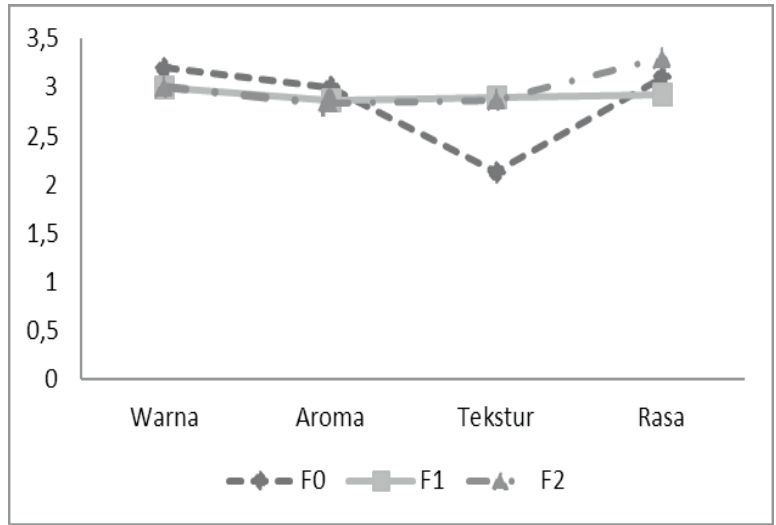

Gambar 1. Uji Daya Terima pada Karakter Biskuit

Hasil perhitungan rata-rata tingkat kesukaan seluruh formula menunjukkan nilai mean tertinggi pada tingkat kesukaan terhadap karakteristik biskuit adalah F2 dengan nilai median sebesar 3,00 . Biskuit F2 (300 g tepung terigu, $90 \mathrm{~g}$ tepung ubi ungu, $10 \mathrm{~g}$ isolat protein kedelai) paling disukai dikarenakan warnanya ungu kecokelatan (tidak terlalu gelap), beraroma khas margarin dan sedikit khas kedelai (tidak terlalu langu), dan tidak terdapat after taste pahit pada rasa biskuit dibandingkan biskuit F1, serta bertekstur lebih renyah dibandingkan $\mathrm{F} 0$.

Hasil uji daya terima pada keseluruhan karakteristik biskuit disajikan pada Gambar 1 . Gambar 1 menggambarkan bahwa penilaian daya terima tertinggi pada karakteristik warna dan aroma biskuit adalah F0, sedangkan pada karakteristik tekstur tertinggi adalah F1 dan penilaian daya terima pada karakteristik rasa tertinggi adalah F2. Perbedaan daya terima biskuit disebabkan oleh perbedaan karakteristik biskuit, sedangkan perbedaan karakteristik biskuit itu sendiri dikarenakan perbedaan jumlah substitusi tepung ubi jalar ungu dan isolat protein kedelai. Hasil analisis menggunakan uji Kruskal Wallis pada penilaian daya terima (warna, aroma, tekstur, dan rasa) didapatkan hasil tidak terdapat perbedaan yang signifikan $(\alpha>0,05)$ pada karakteristik warna, aroma dan rasa antar formula, namun terdapat pengaruh yang signifikan $(\alpha<0,05)$ pada karakteristik tekstur yang kemudian dilanjut dengan uji statistik Mann Whitney untuk mengetahui beda pengaruh antar formula. Hasil uji statistik Mann Whitney menunjukkan bahwa perbedaan yang signifikan pada karakteristik biskuit adalah antara biskuit F0 dengan F1 dan juga antara F0 dengan F2, jika dilihat dari nilai mean rank karakteristik tekstur biskuit F1 dan F2 (biskuit modifikasi) lebih disukai panelis dibanding biskuit F0.

Biskuit substitusi tepung ubi jalar ungu dan isolat protein kedelai sebagai alternatif pemberi makanan tambahan (PMT) untuk ibu hamil selain memiliki daya terima yang tinggi juga harus dapat mencukupi kebutuhan protein ibu hamil yaitu

Tabel 3. Distribusi Kadar Protein per 100 g Biskuit

\begin{tabular}{ccc}
\hline \multirow{2}{*}{ Formula } & \multicolumn{2}{c}{ Kadar Protein (g) } \\
\cline { 2 - 3 } & $\begin{array}{c}\text { Software Nutrisurvey } \\
\mathbf{2 0 0 7}\end{array}$ & Uji Laboratoriun \\
\hline F0 & 5,4 & - \\
F1 & 7,2 & - \\
F2 & 5,7 & 11,93 \\
\hline
\end{tabular}

$10-15 \%$. Kandungan protein pada biskuit berdasarkan perhitungan Nutrisurvey 2007 yang mengacu pada DKBM (1981) dan uji laboratorium disajikan pada Tabel 3, sedangkan persentase kandungan protein biskuit untuk pemenuhan kebutuhan ibu hamil disajikan pada Tabel 4.

Tabel 3 menunjukkan bahwa kandungan protein terendah adalah biskuit F0 (400 g tepung terigu) dan yang tertinggi adalah biskuit F1 (200 $\mathrm{g}$ tepung terigu, 170 tepung ubi jalar ungu dan 30 isolat protein kedelai). Tingginya kandungan protein pada biskuit disebabkan oleh isolat protein kedelai. Semakin tingginya isolat protein kedelai yang disubstitusikan maka semakin tinggi 
Tabel 4. Persentase Kandungan Protein Biskuit untuk Pemenuhan Kebutuhan Ibu Hamil

\begin{tabular}{|c|c|c|c|c|c|}
\hline \multirow[t]{2}{*}{ Kandungan Gizi } & \multicolumn{2}{|c|}{$\begin{array}{l}\text { Zat Gizi per Takaran Saji } \\
\text { (132 g/ } 8 \text { Keping Biskuit) }\end{array}$} & \multirow[t]{2}{*}{ Kebutuhan Ibu Hamil } & \multicolumn{2}{|c|}{$\begin{array}{c}\text { Kontribusi terhadap } \\
\text { Kebutuhan Ibu Hamil (\%) }\end{array}$} \\
\hline & F0 & F2 & & F0 & F2 \\
\hline Energi (Kal) & 400 & 400 & 2430 & 16 & 16 \\
\hline Protein $(\mathrm{g})$ & 7,2 & 7,6 & 76 & 9,3 & 10 \\
\hline
\end{tabular}

kandungan protein pada biskuit. Hal tersebut dikarenakan isolat protein kedelai mengandung minimum 95\% protein kedelai (Koswara, 2013).

Kandungan protein pada biskuit yang diuji di laboratorium lebih tinggi daripada yang dihitung dengan menggunakan sofware nutrisurvey 2007. Hal tersebut dikarenakan bahan makanan yang dihitung di software nutrisurvey merupakan berat bahan mentah sementara pada uji laboratorium adalah setelah pengolahan.

Proses pengolahan selain dapat menurunkan kandungan gizi, juga dapat meningkatkan kandungan gizi produk pangan. Pada proses pengolahan biskuit terdapat peningkatan kandungan protein biskuit. Tinggi rendahnya kandungan protein yang terkandung dalam biskuit dipengaruhi oleh besarnya kandungan air yang hilang dari bahan makanan pada saat pemanasan. Kandungan protein akan semakin meningkat apabila jumlah air yang menghilang semakin banyak. Selain itu juga sifat dari isolat protein kedelai adalah dapat menyerap air dikarenakan memiliki gugus hidrofil yang mampu berikatan dengan air (Basuki, dkk., 2010).

Tabel 4. menunjukkan persentase kandungan protein biskuit F0 (biskuit kontrol) dan biskuit F2 (biskuit modifikasi yang memiliki nilai daya terima tertinggi) terhadap pemenuhan kebutuhan ibu hamil. Berdasarkan data tersebut dapat dilihat bahwa biskuit F2 dapat memenuhi 10-15\% kebutuhan energi dan protein pada ibu hamil dibandingkan dengan F0. Hal tersebut berarti biskuit substitusi tepung ubi jalar ungu dan isolat protein kedelai layak digunakan sebagai alternatif PMT ibu hamil.

\section{KESIMPULAN DAN SARAN}

Penilaian daya terima tertinggi pada karakteristik biskuit yang meliputi warna, aroma, tekstur, dan rasa adalah biskuit F2 (300 g tepung terigu, $90 \mathrm{~g}$ tepung ubi jalar ungu, dan $10 \mathrm{~g}$ isolat protein kedelai). Kandungan protein biskuit F2 pertakaran saji (132 g) adalah 11,93 g. Kandungan protein pertakaran saji (132 $\mathrm{g} /$ porsi) tersebut dapat mencukupi $>10 \%$ dari kebutuhan protein ibu hamil sehingga dapat disimpulkan bahwa biskuit substitusi tepung ubi jalar ungu dan isolat protein kedelai tepat dijadikan alternatif PMT ibu hamil dikarenakan memiliki daya terima yang baik dan juga memiliki kandungan protein sesuai dengan kebutuhan protein ibu hamil.

Ibu hamil dianjurkan untuk mengonsumsi biskuit substitusi tepung ubi jalar ungu dan isolat protein kedelai sebagai PMT ibu hamil dikarenakan dapat memenuhi kebutuhan protein ibu hamil agar terbebas dari KEK.

\section{DAFTAR PUSTAKA}

Agusman. (2013). Pengujian organoleptik. Semarang: Universitas Muhammadiyah Semarang. Diakses dari http://tekpan.unimus. ac.id/wpcontent/uploads/2014/03/UjiOrganoleptik-ProdukPangan.pdf.

Ausa, E.S., Jafar, N., \& Indriasari, R. (2013). Hubungan pola makan dan status sosial ekonomi dengan kejadian KEK pada ibu hamil di Kabupaten Gowa tahun 2013. Diakses dari http://repository.unhas.ac.id/ bitstream/handle/123456789/5508/jurnal. pdf? sequence $=1$.

Basuki, E.K., Yulistiani, R., \& Dwi, N. (2010). Kajian penambahan minyak dan isolat protein kedelai pada sosis ikan layur. Neptunus Jurnal Kelautan,16(2), 114-120. Diakses dari http:// docplayer.info/38301876-Kajian-penambahanminyak-dan-isolat-protein-kedelai-pada-sosisikan-layur.html.

Claudia, R., Estiati, T., Ningtyas, D.W., \& Widyastuti, E. (2015). Pengembangan biskuit dari tepung ubi jalar oranye (Ipomoea batatas L.) dan tepung jagung (Zea mays). Jurnal Pangan dan Agroindustri, 3(4), 1589-1595. 
Diakses dari http://www.jpa.ub.ac.id/index.php/ jpa/article/view/284.

Direktorat Komposisi Bahan Makanan. (1981). Daftar Komposisi Bahan Makanan. Jakarta: Departemen Kesehatan.

Endasari, R., \& Nugraheni, D. (2012). Pengaruh berbagai cara pengolahan sari kedelai terhadap penerimaan organoleptik. artikel dipresentasikan pada Seminar Nasional Optimalisasi Pekarangan, Semarang. Diakses dari jateng.litbang.pertanian. go.id/ind/maged/artikel/publikasipenelitianpen yuluh/2012/hal $\% 20468-475 \% 20$ r.endrasari $\% 20$ $-\% 20$ div.pdf.

Ekafitri, R. \& Isworo, R. (2014). Pemanfaatan kacang-kacangan sebagai bahan baku sumber protein untuk pangan darurat. PANGAN, 23(2), 134-145. Diakses dari jurnalpangan.com/index. php/pangan/article/view/57/52.

Fiani, M., \& Japarianto, E. (2012). Analisa pengaruh food quality dan brand image terhadap keputusan pembelian roti kecil toko roti Ganepis di Kota Solo. Jurnal Manajemen Pemasaran, 1(1):1-6.

Hardoko, L.H., dan Siregar, T.M. (2010). Pemanfaatan ubi jalar ungu (Ipomoea batatas L. Poir) sebagai pengganti sebagian tepung terigu dan sumber antioksidan pada roti tawar. Jurnal Teknologi dan Industri Pangan, 21(1), 25-32. Diakses dari http://mail.student.ipb.ac.id. index.php/jtip/article/view/2414.

Kementerian Kesehatan Republik Indonesia. (2010). Pedoman gizi ibu hamil dan pengembangan makanan tambahan ibu hamil berbasis pangan lokal. Jakarta: Direktorat Bina Gizi Masyarakat, Kementerian Kesehatan RI.

Kementerian Kesehatan Republik Indonesia. (2014). Pedoman gizi seimbang. Jakarta: Direktorat Jenderal Bina Gizi dan KIA.

Koeswardhani, M. (2016). Dasar-dasar teknologi pangan. Jakarta: Universitas Terbuka. Diakses dari http://repository.ut.ac.id/4619/PANG4312M1.pdf.

Koswara, S. (2013). Teknologi pengolahan umbi-umbian bagian 5: pengolahan ubi jalar. Bogor: Institut Pertanian Bogor. Diakses dari http://seafast.ipb.ac.id/tpc-project/wp-content/ uploads/2013/10/5-pengolahanubi jalar ungu.

Marta, H., \& Tensiska. (2013). Pembuatan berbagai produk ubi jalar dalam upaya diversifikasi pangan dan peningkatan gizi msyarakat di Desa Sekarwangi dan Desa Cilangkap Kecamatan Buahdua Kabupaten Sumedang. Jurnal Aplikasi
Ipteks untuk Masyarakat, 2(2), 85-92. Diakses dari http://jurnal.unpad.ac.id/dharmakarya/ article/view/8220/3768.

Mayasari, R. (2015). Kajian karakteristik biskuit yang dipengaruhi perbandingan tepung ubi jalar (Ipomoea batatas L.) dan tepung kacang merah (Phaseolus vulgaris L.) (Artikel Ilmiah, Universitas Pasundan, Bandung). Diakses dari http://repository.unpas. ac.id/32 11/2/ARTIKEL\%20KAJIAN\%20 KARAKTERISTIK \% 20BISKUIT \% 20 YANG\%20DIPENGARUHI\%20PERBAN. pdf.

Mervina. (2009). Formulasi biskuit dengan substitusi tepung ikan lele dumbo (Clarias gariepenus) dan isolat protein kedelai (Glycine max) sebagai makanan potensial untuk anak balita kurang gizi (Skripsi, Institut Pertanian Bogor, Bogor). Diakses dari http://core.ac.uk/ download/pdf/32347140.pdf.

Mervina, Kusharto, C. M., \&Marliyati, S.A. (2012). Formulasi biskuit dengan substitusi tepung ikan lele dumbo (Clarias gariepinus) dan isolat protein kedelai (Glycine max) sebagai makanan potensial untuk anak balita gizi kurang. Jurnal Teknologi dan Industri Pangan, 23(1), 9-16. Diakses dari .http://journal.ipb.ac.id/index.php/ jtip/article/view/5287/4229

Muliawati, S. (2013). Faktor penyebab ibu hamil kekurangan energi kronis di Puskesmas Sambi kecamatan Sambi Kabupaten Boyolali tahun 2012. Jurnal Ilmiah Rekam Medis dan Informatika Kesehatan, 3(3), 40-50. Diakses dari http://www.apikescm.ac.id/ejumalinfokes/ index.php/infokes/article/view/115/112.

Purwanto \& Hersoelistyorini, W. (2011). Studi pembuatan makanan pendamping asi (mp-asi) menggunakan campuran tepung kecambah kacang kedelai, kacang hijau, dan beras. Jurnal Pangan dan Gizi, 2(3), 43-4. Diakses dari http:// download.portalgaruda.org/article.php?article. pdf.

Rosidah. (2014). Potensi ubi jalar ungu sebagai bahan baku industri pangan. Jurnal Teknobuga, 1(1), 44-52. Diakses dari https://journal. unnes.ac.id/nju/index.php/teknobuga/article/ view/6403/4858.

Santoso, S.P. (2005). Teknologi pengolahan kedelai (teori dan praktek) Malang: Universitas Widyagama Malang. Diakses dari http://s3.amazonaws.com/academia.edu. documents/33238027/teknologi-pengolahan- 
kedelai-teori-dan-praktek.pdf.

Supariasa IDN, Bakri B, \& Fajar I. (2002). Penilaian status gizi. Jakarta: EGC.

Syari, M., Serudji, S., \& Mariati U. (2015). Peran asupan gizi makronutrien ibu hamil terhadap berat badan lahir rendah di kota Padang. Jurnal Kesehatan Andalas, 4(3), 1-8. Diakses dari http://jurnal.fk.unand.ac.id/index.php/jka/ article/view/355.

Williams \& Margareth. (2001). Food experimental perspective, forth Edition. New Jersey: Prentice Hall.

Winarno, F.G. (2004). Kimia pangan dan gizi. Jakarta: Gramedia Pustaka Utama. 